\title{
Genetic characterization and phylogenetic study of Indonesian cuscuses from Maluku and Papua Island based on 165 rRNA gene
}

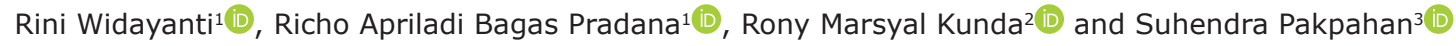 \\ 1. Department of Biochemistry and Molecular Biology, Faculty of Veterinary Medicine, Universitas Gadjah Mada, \\ Yogyakarta, Indonesia; 2. Biology Study Program, Faculty of Mathematics and Natural Sciences, Universitas \\ Pattimura, Ambon, Indonesia; 3. Research Center for Biology, Indonesian Institute of Sciences (LIPI), Cibinong, \\ West Java, Indonesia. \\ Corresponding author: Suhendra Pakpahan, e-mail: suhendrapakpahan@gmail.com \\ Co-authors: RW: rini_widayanti@ugm.ac.id, RABP: richo.apriladi.b@mail.ugm.ac.id, RMK: ronykunda@gmail.com \\ Received: 04-06-2020, Accepted: 22-09-2020, Published online: 04-11-2020
}

doi: www.doi.org/10.14202/vetworld.2020.2319-2325 How to cite this article: Widayanti R, Pradana RAB, Kunda RM, Pakpahan S (2020) Genetic characterization and phylogenetic study of Indonesian cuscuses from Maluku and Papua Island based on 16S rRNA gene, Veterinary World, 13(11): 2319-2325.

\begin{abstract}
Background and Aim: Indonesian cuscuses are now becoming scarce because of the reduction of habitat and poaching. Further, molecular characterization of Indonesian cuscuses is still very lacking. This study aimed to determine genetic markers and phylogenetic relationships of Indonesian cuscuses based on $16 S$ rRNA gene sequences.

Materials and Methods: This study used 21 cuscuses caught from two provinces and 16 islands: 13 from Maluku and eight from Papua. Cuscus samples were taken by biopsy following ethics guidelines for animals. The genome isolation was done using gSYNC DNA Mini Kit (Geneaid Biotech Ltd., Taiwan). The 16S rRNA gene was amplified by primers (16SKUSAF and 16SKUSAR), and the polymerase chain reaction product obtained was 1875 base pair (bp). The analysis of genetic characterization and the phylogenetic relationship was performed using MEGA version X software (https://www. megasoftware.net/).
\end{abstract}

Results: $16 S$ rRNA gene sequencing attained 1598 bp for all samples. Based on the $16 S$ rRNA nucleotide sequences, cuscuses from Papua and Maluku belong to the genus Phalanger and Spilocuscus. Phalanger spp. and Spilocuscus spp. from Papua can be distinguished from Phalanger and Spilocuscus from Maluku, except Spilocuscus from Ternate has a very close relationship with cuscus from Sentani, Papua.

Conclusion: Indonesian cuscuses were derived into two clades based on $16 S r R N A$ gene sequence, one group to genus Phalanger and another group to Spilocuscus.

Keywords: Indonesian cuscuses, Maluku, Papua, Phalanger, phylogeny, Spilocuscus.

\section{Introduction}

Animal distribution studies are increasingly being conducted, so the characterization of each species needs to be carried out both morphologically and molecularly. One animal originating from the Wallace line is the small Sulawesi cuscus (Strigocuscus celebensis); another is Sulawesi bear cuscus (Ailurops ursinus). There are at least 20 additional species which belong to the family Phalangeridae [1-3]. A. ursinus is spread throughout Sulawesi and nearby islands in Togian, Peleng, Muna, Buton, and Lirung (Talaud Islands). Spilocuscus maculatus, described by Desmarest [4], has a range that extends from Queensland (Australia), through Papua, to Buru and Caram, and the small island of Selayar, at the tip of the Southeast Sulawesi. Peninsula cuscus is an Australian animal, marsupial mammal, belonging to the family

Copyright: Widayanti, et al. Open Access. This article is distributed under the terms of the Creative Commons Attribution 4.0 International License (http://creativecommons.org/licenses/ by/4.0/), which permits unrestricted use, distribution, and reproduction in any medium, provided you give appropriate credit to the original author(s) and the source, provide a link to the Creative Commons license, and indicate if changes were made. The Creative Commons Public Domain Dedication waiver (http:// creativecommons.org/publicdomain/zero/1.0/) applies to the data made available in this article, unless otherwise stated.
Phalangeridae, whose distribution is limited in East Indonesia (Sulawesi, Maluku, and Papua), Australia, and Papua New Guinea. From the five genus cuscus, four genera are found in Indonesia, namely, Ailurops, Phalanger, Spilocuscus, and Strigocuscus, and there are at least 24 species of cuscus spread across the three islands [5-7]. In Papua, two genera were found, namely, Phalanger (bottled cuscus) and Spilocuscus (spotted cuscus); in Maluku, there are two genera found, namely, Phalanger and Spilocuscus; and in Sulawesi, the genus Spilocuscus and Ailurops are found, which are endemic species in Sulawesi Island [8-10]. This research is significant because Indonesian cuscuses are now beginning to become scarce due to the decreasing habitat it occupies, many local people are hunting for consumption, trade, and, in some communities, ritual purposes [11,12].

Cuscus is one of the protected wildlife in Indonesia based on the decree of the Indonesian Ministry of Agriculture No. 247/KPTS/UM4/1979 and PP. No. 7 of 1999 concerning Preservation of Plants and Animals. Efforts to maintain the preservation of these animals need to be done in situ and ex situ conservation. The data from these animals, both morphologically and genetically, are lacking, so the molecular characteristics 
need to be studied more closely. Latinis [13] has researched hunting cuscus in Central Maluku. Fatem and Sawen [14] identified cuscus in the northern coastal region of Manokwari, Papua, based on its morphological characteristics. Molecular research on cuscus has been carried out by Munemasa et al. [15] using the mitochondrial genome but at the level of the Phalangeridae family. Molecular studies at the species level have never been carried out. According to the previous studies, the NADH dehydrogenase subunit 3 (ND3) gene sequence, the 4L NADH dehydrogenase subunit (ND4L) gene, and 12 rRNA gene can be used as genetic markers of Tarsius bancanus from Sumatra, Kalimantan with Tarsius from Sulawesi [16-18].

This study aimed to obtain nucleotide sequences and measure diversity using $16 S \mathrm{rRNA}$ mitochondrial gene in cuscus from Maluku and Papua. These mitochondrial DNA sequences are unique and can be used as genetic markers for species identification. The $16 \mathrm{~S}$ rRNA gene has been widely used for phylogenetic study and detection in other species [19-22]. It is expected that the nucleotide diversity of each cuscus species can be used as genetic markers and can determine the phylogenetic relationship of the cuscuses from Maluku and Papua. It is hoped that by identifying genetic markers will help conservation efforts, especially for animals that have lost their habitat and need to be conducted ex situ. The information gained from these efforts can apply to other endangered species that are threatened with extinction, preserving the biological wealth in Indonesia.

\section{Materials and Methods}

\section{Ethical approval}

This study was approved by the Animal Ethics Committee for using Animal and Scientific Procedures in the Faculty of Veterinary Medicine, Universitas Gadjah Mada, Indonesia.

\section{Sample collection, study period, and location}

Cuscus samples were taken from their natural habitat, namely, Maluku Province (13 individuals) and Papua Province (8 individuals) (Table-1). All cuscus samples were identified based on morphological characteristics (Figure-1) and sample tissues were preserved in RNA latter buffer (Qiagen, Germany). The Indonesian cuscus samples in this study were unrelated genetically because they were taken individually from the habitat of each location. This research was conducted from January to June 2020, starting from sample collection to data analysis.

\section{Genome isolation}

Total DNA was extracted from tissue biopsy $(30 \mathrm{mg})$. Isolation and purification of DNA were performed using a DNA Isolation Kit (Qiagen). The isolated DNA was detected after migration on a $1 \%$ agarose gel using a $1 \times$ TBE buffer in the Submarine Electrophoresis device (Hoefer, USA). We observed the isolates with the help of ultraviolet (UV) light $(\lambda=260 \mathrm{~nm})$ after the gel was stained with Bioatlas (Genaid, Taiwan). The isolated DNA was then stored at $-20^{\circ} \mathrm{C}$ before being used for the next step.

\section{Primer design}

The primers are designed using the Primer 3 output program (http://www-genome.wi.mit.edu/cgi.bin/ primr3.cgi/results_from-primer3) based on the mitochondrial sequences of Phalanger vestitus (Access number AB241057.1). The sequence of the primers for the amplification of the $16 S$ rRNA gene is presented in Table-2.

\section{Amplification of the 165 rRNA gene by polymerase chain reaction (PCR)}

Genomic DNA was used as DNA template for the amplification of $16 S$ rRNA gene. DNA amplification by PCR in this study used an Infinigen PCR machine. Amplification of the $16 S$ rRNA gene each using a self-designed pair of primers based on $P$. vestitus mitochondrial genome sequence from GenBank

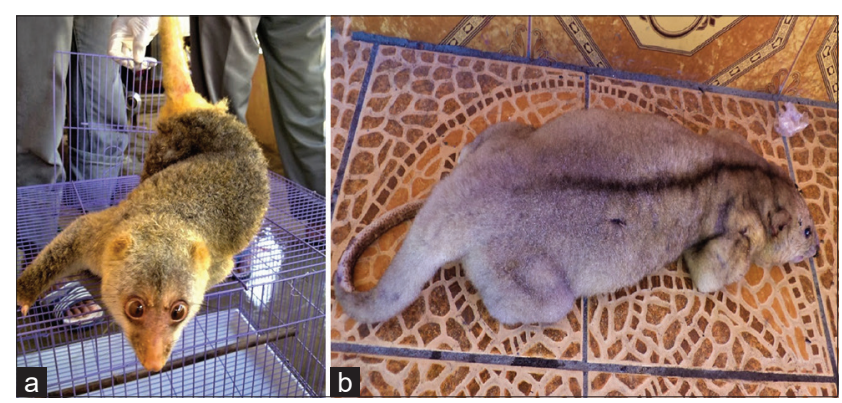

Figure-1: The cuscuses were from Maluku (a) and Papua (b).

Table-1: Origin of cuscus samples from Maluku and Papua Island.

\begin{tabular}{ll}
\hline & Origin of cuscus \\
\hline Maluku Island & Papua Island \\
\hline Allang P. Ambon & Moor Nabire Island \\
Geser Island & Nabire Island \\
Gorom Island & Sentani Jayapura Island \\
Halmahera Island & Wanggar Nabire Island \\
Hatu Ambon Island & Yaro Nabire Island \\
Kariu Haruku Island & \\
Lakor Island & \\
Manipa Island & \\
North Seram Island & \\
South Seram Island & \\
Soya Ambon Island & \\
\hline
\end{tabular}

Table-2: Primer sequences for amplifying $16 S$ rRNA gene.

\begin{tabular}{|c|c|c|c|}
\hline Primer & Sequence & $\begin{array}{l}\text { Product } \\
\text { size (bp) }\end{array}$ & $\begin{array}{l}\mathrm{Tm} \\
\left({ }^{\circ} \mathrm{C}\right)\end{array}$ \\
\hline 16SKUSAF & $\begin{array}{l}5^{\prime} \text { TTAGGAAGGCA } \\
\text { АTTGCTAGG } 3^{\prime}\end{array}$ & 1875 & 51 \\
\hline 16SKUSAR & $\begin{array}{l}5^{\prime} \text { CCGTCACCC } \\
\text { TCCTCAATTA } 3^{\prime}\end{array}$ & & 53 \\
\hline $16 S K U S B F$ & $\begin{array}{l}5^{\prime} \text { TTAGAAAAGCA } \\
\text { ATTGCTAGG } 3^{\prime}\end{array}$ & 1875 & 54 \\
\hline 16SKUSBR & $\begin{array}{l}\text { 5' CGTCACCCTC } \\
\text { CTCAATTA 3' }\end{array}$ & & 53 \\
\hline
\end{tabular}


(access number AB241057.1), as shown in Table-1. DNA amplification was carried out under the following conditions: Initial denaturation for $2 \mathrm{~min}$ at temperature $94^{\circ} \mathrm{C}$ then followed by $94^{\circ} \mathrm{C}$ for $30 \mathrm{~s}$ for denaturation, $49^{\circ} \mathrm{C}$ for $45 \mathrm{~s}$ for primary attachment (annealing), and $72^{\circ} \mathrm{C}$ for 1 min $45 \mathrm{~s}$ for elongation; amplification was carried out as many as 35 cycles, then ending with $5 \mathrm{~min}$ at $72^{\circ} \mathrm{C}$.

PCR products were detected by $1.5 \%$ agarose gel using a $1 \times$ TBE buffer in the Submarine Electrophoresis device (Hoefer, USA). The observation was carried out on UV transilluminator $(\lambda=260$ $\mathrm{nm}$ ) after the gel was stained with Bioatlas (Genaid). DNA markers with a size of $1000 \mathrm{bp}$ are used as indicators of molecular weight.

\section{DNA sequencing}

The amplified PCR product was purified using the GFX Column purification kit, then used as DNA template for sequencing. For each sample, two sequencing reactions were carried out using the forward and reverse primers. Sequencing was performed on all $16 S$ rRNA gene PCR products that good sequencing results were marked with a single peak spectrophotogram graph and no noise.

\section{Amplification of 165 rRNA gene by PCR technique}

Genome amplification of 21 cuscus samples from Papua and Maluku resulted in excellent bands, with a length of approximately $1875 \mathrm{bp}$. Amplicons were visualized using $1 \%$ agarose gel electrophoresis with $1 \mathrm{~kb}$ DNA ladder as a molecular weight indicator (Figure-2). The PCR products were sequenced using forward primers and reverse primers used for the amplification process.

\section{Statistical analysis}

The multiple alignments of $16 \mathrm{Sr} R N A$ gene nucleotides were analyzed using ClustalW software [23]. The sequences of $16 S r R N A$ gene were analyzed by MEGA software version 7 [24]. Genetic distance was analyzed by the Kimura method with two parameters [25]. PCR products were sequenced, both forward and reverse. Sequencing results were aligned using the ClustalW program. Reverse sequences were used as comparisons of forward sequences to obtain an accurate sequence result. The phylogenetic tree was constructed based on nucleotide sequences by the neighbor-joining method with a bootstrap value $1000 \times$. The cuscus used as a comparison and was taken from GenBank data including P. vestitus (Access number AB241057.1), S. maculatus (KJ868160.1), Phalanger gymnotis (KJ868142.1), Phalanger orientalis (AY228381.1), and Trichosurus vulpecula (AF357238.1).

\section{Results and Discussion}

\section{Genetic variation}

Twenty-one cuscus samples from Papua and Maluku were analyzed based on sequences of forward and reverse $16 \mathrm{~S} r R N A$ sequences. Forward and reverse sequences were used for the editing process by observing sequence electropherogram. Cuscus (Allang P. Ambon) was a basis comparison to determine the site variables for other cuscuses. The dot on the alignment image showed homology with cuscus (Allang P. Ambon). There were 166 site variables in the amplified 16S gene (Figures 3-5). Some cuscus samples had high similarity with cuscus (Allang P. Ambon), namely, cuscus Halmahera, Manipa, South Seram, Soya Ambon, and Nabire Island.

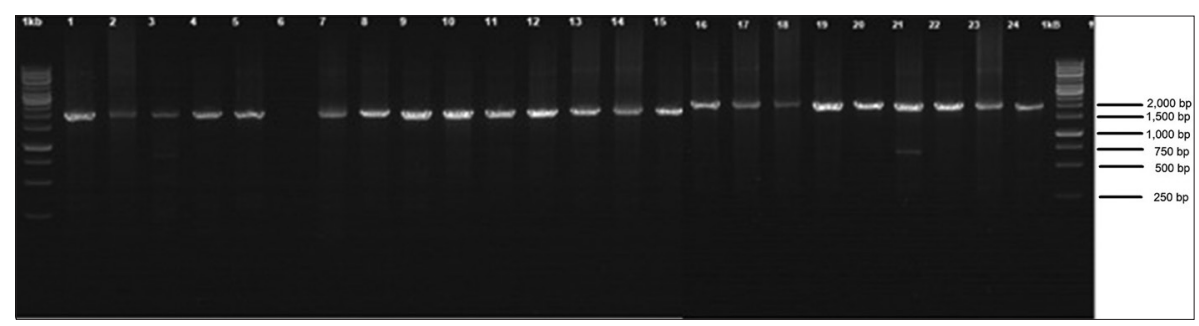

Figure-2: Polymerase chain reaction product of $16 S$ rRNA cuscus from Papua and Maluku in agarose gel $1 \%$.

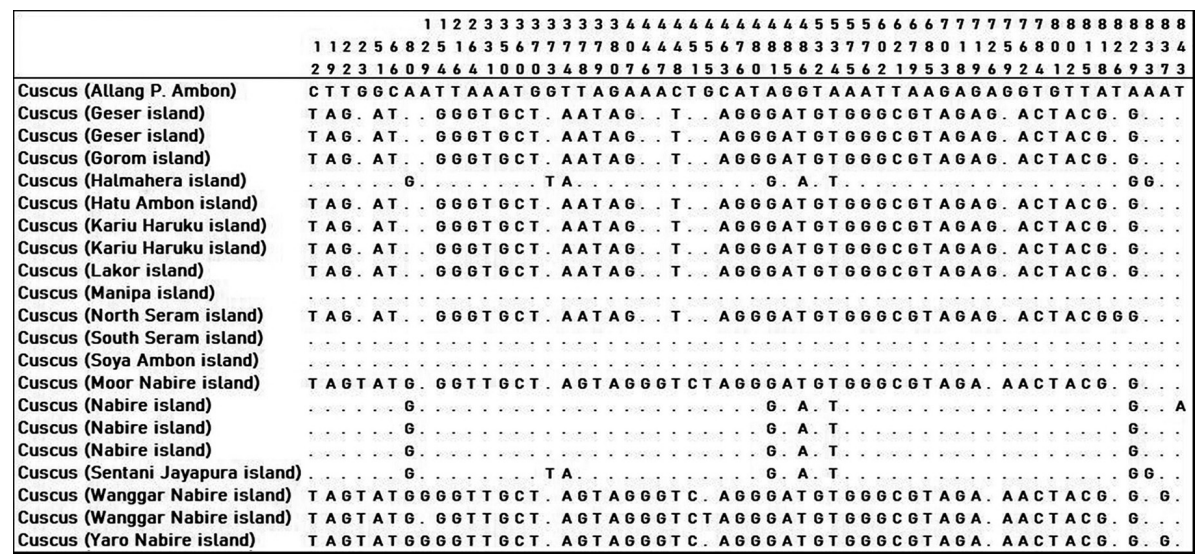

Figure-3: Variable sites 12-843 on $16 \mathrm{~S}$ gene of cuscus from Maluku and Papua. 


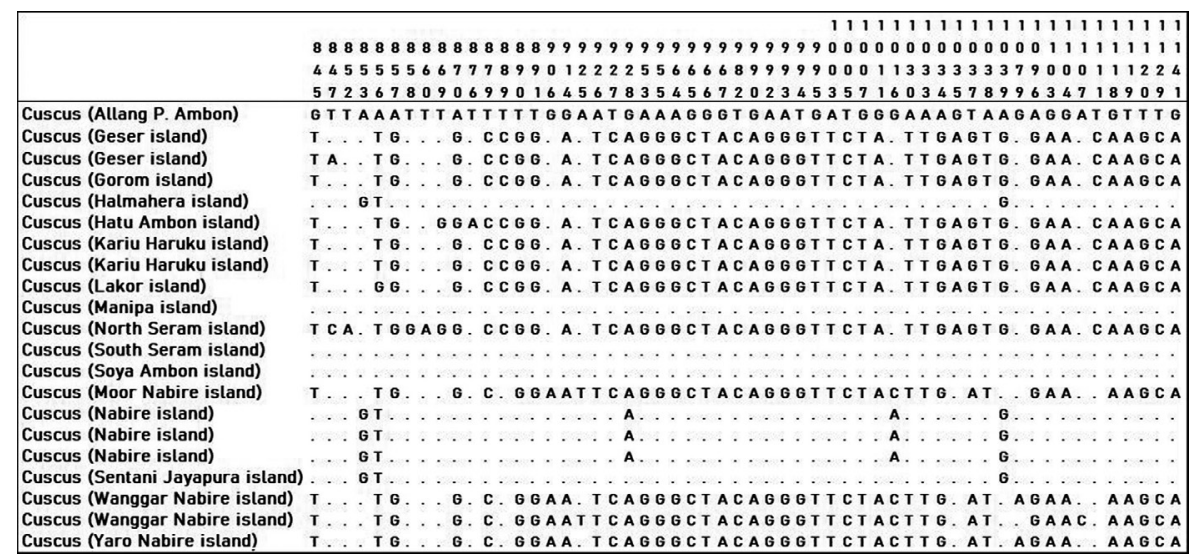

Figure-4: Variable sites 845-1141 on 16S gene of cuscus from Maluku and Papua.

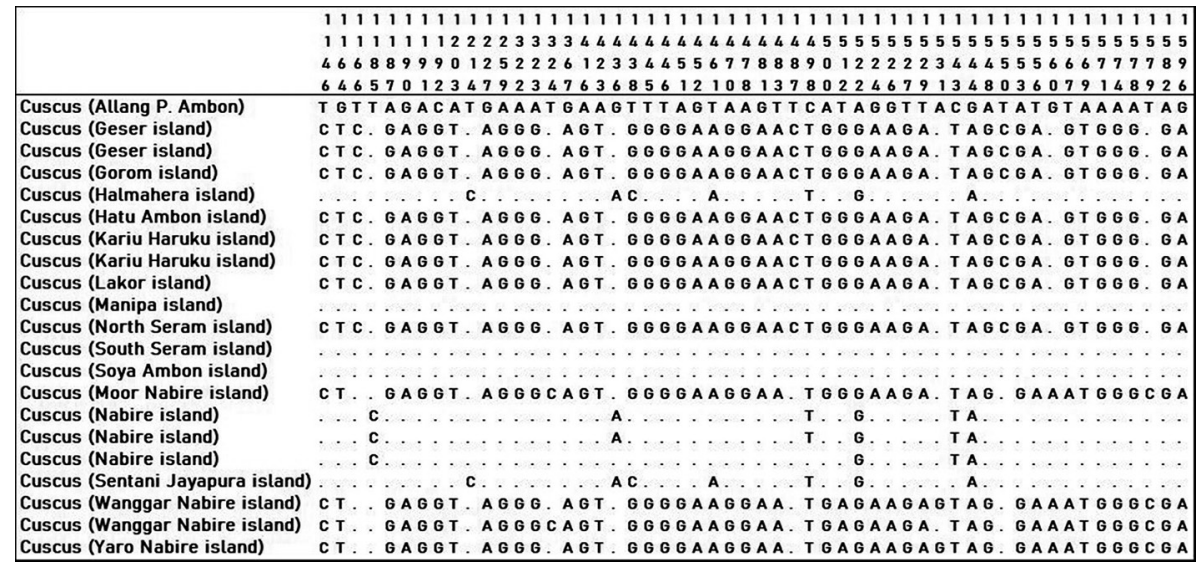

Figure-5: Variable sites 1146-1596 on 16S gene of cuscus from Maluku and Papua.

The alignment sequence showed that there were two groups of cuscuses in this study which had similarities in the $16 \mathrm{~S}$ gene sequence. The first group is cuscus (Allang P. Ambon, Halmahera, Manipa, South Seram, Soya Ambon, and Nabire), the second group is cuscus (Geser, Gorom, Hatu Ambon, Kariu Haruku, Lakor, North Seram, Moor Nabire, Wanggar Nabire, and Yaro Nabire). This separation of groups did not follow their area of origin cuscuses.

\section{Genetic relationship between cuscus from Maluku and Papua}

The phylogenetic tree was constructed using the neighbor-joining method. Cuscuses from Maluku and Papua were divided into two clades (Figure-6), which means that cuscuses were split into two genera. Clade A1 was the cuscuses from Papua belonging to the genus Phalanger, while clade A2 was the cuscuses from Maluku belonging to the genus Phalanger. Clade B1 was the cuscuses from Papua belonging to the genus Spilocuscus, while clade B3 was the cuscuses from Maluku belonging to the genus Spilocuscus. In the B2 clade, the cuscuses came from Papua and Maluku.

The number of base substitutions per site from averaging over all sequence pairs between groups is shown (Table-3). Standard error estimates are shown above the diagonal. Analyses were conducted using the maximum composite likelihood model [1]. All positions containing gaps and missing data were eliminated. There were 1543 positions in the final dataset.

\section{Evolutional history}

The evolutionary history was inferred using the neighbor-joining method [26]. The optimal tree with the sum of branch length $=0.40235225$ is shown. The percentage of replicate trees in which the associated taxa clustered together in the bootstrap test (1000 replicates) is shown next to the branches [27]. The tree is drawn to scale, with branch lengths in the same units as those of the evolutionary distances used to infer the phylogenetic tree. The evolutionary distances were computed using the Tamura-Nei method [28] and are in the units of the number of base substitutions per site. This analysis involved 28 nucleotide sequences, both the samples of current study and samples from GenBank. All ambiguous positions were removed for each sequence pair (pairwise deletion option). There were 1598 positions in the final dataset. In Figure-2, the cuscuses from Papua and Maluku belong to two genera, namely, Phalanger and Spilocuscus. In the group of Phalanger, those from Papua and Maluku had the closest relationship with $P$. vestitus, while Spilocuscus type had the closest relationship with S. maculatus. Two species of cuscus are commonly hunted in Maluku, S. maculatus and P. orientalis. $S$. maculatus is known as the spotted cuscus. The distribution of $S$. maculatus includes New Guinea, Aru, 
Table-3: Estimates of evolutionary divergence over sequence pairs between groups.

\begin{tabular}{lcccc}
\hline Cuscus & S. macalatus & Phalanger & Cuscus from Ambon & Cuscus from Papua \\
\hline S. macalatus* & & 0.008 & 0.006 & 0.004 \\
Phalanger* & 0.091 & & 0.006 & 0.006 \\
Cuscus from Maluku & 0.063 & 0.076 & & 0.005 \\
Cuscus from Papua & 0.045 & 0.081 & 0.054 & \\
\hline
\end{tabular}

*From GenBank data, Spilocuscus maculatus (KJ868160.1), Phalanger vestitus (access number AB241057.1)

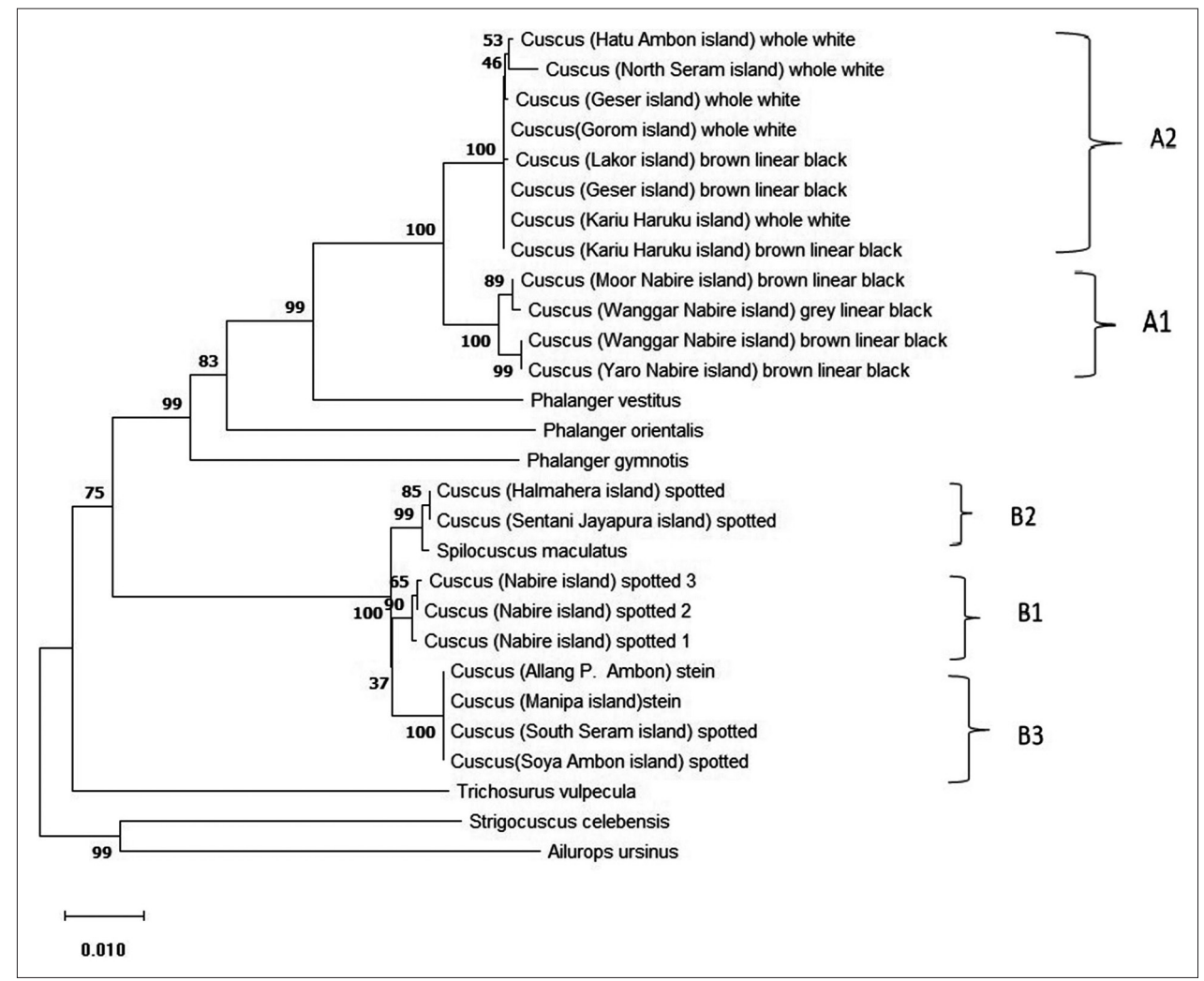

Figure-6: Evolutionary relationships of Indonesian cuscuses (with color of coat) and some cuscuses from GenBank database Phalanger vestitus (Access number AB241057.1), Spilocuscus maculatus (KJ868160.1), Phalanger gymnotis (KJ868142.1), Phalanger orientalis (AY228381.1), and Trichosurus vulpecula (AF357238.1).

Kei, Buru, Seram, Ambon, Selayer, Banda, Pandjang, Timor, and Cape York Peninsula, Australia. Prehistory and archeology of the cuscus evidenced that P. orientalis may have been actively introduced to Maluku, Seram, Buru, Sanana, and the Kai Islands as early as 6500 years ago. P. vestitus and $S$. maculatus were found in Papua and Maluku region [13,29]. The recent study on cuscus from Maluku, Kusumaningrum, and Abinawanto [30] studied cuscuses based on COI gene sequences and found that there were two types of cuscus, namely, $S$. maculatus and $P$. vestitus.

The results showed that, for the cuscus from Maluku and Papua, each origin included two genera, namely, the genus Phalanger and Spilocuscus. Widayanti et al. [8] studied molecular characterization of cuscus from Maluku and Papua Island based on the NADH dehydrogenase subunit 1 gene, grouping cuscus from Papua and Maluku became two genera Phalanger and Spilocuscus and classified into Phalanger spp. and S. maculatus species. The taxonomic review based on the biogeographic history of Phalangeridae is complicated because the geological history of Southeast Asia is very complicated to describe. As a result, the historical interpretation of phalangerids biogeography provided can only be temporary [1-3]. The molecular phylogeny presented in this study is thought to reflect better the evolutionary relationships of Phalangeridae that differ from previous taxonomic determinations; the molecular phylogeny tree shows high suitability using statistical calculations [31].

Cuscuses of Papua and Maluku belonging to the genus Phalanger (Figure-6) showed that the two cuscus groups are separated in different sub-branches and show that Phalanger from Papua and Maluku can be distinguished [8,9]. Usmany et al. [11] reported that four types of cuscus lived in Seram (Maluku), namely, brown cuscus (P. orientalis), gray cuscus ( $P$. vestitus), white cuscus (Phalanger ursinus), and spotted cuscus (S. maculatus). These four types of cuscus showed similarities in morphology. The spotted cuscus and gray cuscus have similarities of the earlobe, which are covered with hair. Still, white cuscus and brown cuscus are similar in that the earlobe is not covered with 
hair [14]. Likewise, for Papua and Maluku cuscuses belonging to the genus Spilocuscus are also in different sub-branches. However, except for Tobelo (ternate) cuscus, the cuscus has historically been brought along with the migration of people from Papua to Maluku (Ternate) so that cuscus from Ternate has a very close relationship with those from P. Sentani, Papua [13,29].

\section{Conclusion}

Cuscuses from Papua and Maluku based on the $16 S$ rRNA gene nucleotide sequence are classified in the genus Phalanger and Spilocuscus. Phalanger spp. and Spilocuscus from Papua can be distinguished from Phalanger and Spilocuscus from Maluku, except Spilocuscus from Ternate has the closest relationship with cuscus from Sentani, Papua. The 16S rRNA gene can be used to identify genetic markers and differentiate cuscus species from Maluku and Papua. Genetic characterization information, especially genetic markers, is needed to carry out the conservation and breeding of each species.

\section{Authors' Contributions}

RW and SP designed this research and collected cuscus samples for this study. SP, RABP, and RMK conducted research in the laboratory. RW and SP analyzed the data and wrote the manuscript. All authors have read and approved the final manuscript.

\section{Acknowledgments}

The authors are thankful to the Faculty of Veterinary Medicine, Universitas Gadjah Mada, Indonesia, for providing funding through the Research Development Section through BPPTN-BH FKH UGM No. 1678/J01.1.22/HK4/2016. The authors also thankful to the Faculty of Biotechnology, Duta Wacana Christian University, for the excellent support in manuscript writing.

\section{Competing Interests} interests.

The authors declare that they have no competing

\section{Publisher's Note}

Veterinary World remains neutral with regard to jurisdictional claims in published institutional affiliation.

\section{References}

1. Colgan, D.J., Flannery, T.F., Trimble, J. and Aplin, K.P. (1993) Electrophoretic and morphological analysis of the systematics of the Phalanger orientalis (Marsupialia) species complex in Papua-New-Guinea and the SolomonIslands. Aust. J. Zool., 41(4): 355-378.

2. Norris, C.A. and Musser, G.G. (2001) Systematic revision within the Phalanger orientalis complex (Diprotodontia, Phalangeridae): A third species of lowland gray cuscus from New Guinea and Australia. Am. Mus. Nov., 1(3356): 1-20.

3. Molloy, S.W., Davis, R.A. and van Etten, E.J. (2016) Incorporating field studies into species distribution and climate change modelling: A case study of the koomal Trichosurus vulpecula hypoleucus (Phalangeridae). PLoS
One, 11(4): 154161.

4. Desmarest, A.G. (1817) Crustacés fossiles. In: Nouveau Dictionnaire d'Histoire Naturelle, Appliquée aux Arts, à L'agriculture, à L'economie Rurale et Domestique, à La Médecine. $2^{\text {nd }}$ ed. Deterville, Paris. p495-519.

5. Menzies, J. (2011) A Handbook of New Guinea's Marsupials and Monotremes. University of Papua New Guinea Press, Papua New Guinea.

6. Petocz, R.G. (1994) Mamalia Darat Irian Jaya. Grafitipers, Jakarta.

7. Flannery, T.F. (1994) Possums of the World: A Monograph of the Phalangeroidea. GEO, Sydney, New South Wales, Australia.

8. Widayanti, R., Agustianti, T.S., Kunda, R.M. Pakpahan, S. (2016) Phylogenetic relationship of cuscuses (Marsupialia: Phalangeridae) from Papua and Maluku based on mitochondrial sequences of NADH dehydrogenase subunit 1 gene. Biotechnology, 15(1-2): 17-25.

9. Kunda, R.M., Handayani, N.S.N., Wijayanto, H. and Widayanti, R. (2017) DNA barcoding of cuscuses (Marsupialia: Phalangeridae) from Maluku and Papua. Asian J. Anim. Vet. Adv., 12(5): 227-238.

10. Nugraha, R. and Mustari, A.H. (2017) Habitat characteristics and diet of bear cuscus (Ailurops ursinus) in Tanjung Peropa wildlife reserve, Southeast Sulawesi. J. Wasian, 4(2): 55-68.

11. Usmany, M., Tuaputty, H. and Kakisina, P. (2015) Cuscus (Family Phalangeridae) phenotype study in Lumoli Rural District Breeding Farm, Piru, Maluku. J. Sain Vet., 33(2): 180-189.

12. Sawen, D. and Sinery, A.S. (2020) The feed plants species of cuscus Phalanger orientalis in Yamna Island, Sarmi Regency. World J. Adv. Res. Rev., 6(1): 31-39.

13. Latinis, K. (1996) Hunting the cuscus in Western Seram: The role of the Phalanger in subsistence economies in Central Maluku. Cakalele, 7(1): 17-32.

14. Fatem, S. and Sawen, D. (2007) The species of cuscus in Northern coastal areas of Manokwari, Papua. Biodivers. $J$. Biol. Divers., 8(3): 86-91.

15. Munemasa, M., Nikaido, M., Donnellan, S., Austin, C.C., Okada, N. and Hasegawa, M. (2006) Phylogenetic analysis of Diprotodontian marsupials based on complete mitochondrial genomes. Genes Genet. Syst., 81(3): 181-191.

16. Widayanti, R., Handayani, N.S.N. and Budiarsa, I. (2011) Keragaman genetik gen penyandi dehydrogenase Subunit 3 mitokondria pada monyet hantu (Tarsius sp.) J. Vet., 12(1): 26-33.

17. Widayanti, R. and dan Susmiati, T. (2012) Studi keragaman genetik Tarsius sp. Asal Kalimantan, Sumatera, dan Sulawesi berdasarkan sekuen gen NADH dehidrogenase sub-unit 4L (ND4L). J. Kedokt. Hewan, 6(2): 105-111.

18. Widayanti, R., Wijayanto, H., Wendo, W.D. and Kunda, R.M. (2015) Identification of genetic diversity $12 \mathrm{Sr}$ RNA genes as genetic marker for determining species cuscus. J. Vet., 16(2): 227-235.

19. Saikia, D.P., Kalita, D.J., Borah, P., Sarma, S., Barman, N.N. and Dutta, R. (2015) Differentiation of sheep and goat species by PCR-RFLP of mitochondrial $16 S$ rRNA gene. $J$. Anim. Res., 5(2): 213-217.

20. Abdullah, H.H., El-Molla, A., Salib, F.A., Allam, N.A., Ghazy, A.A. and Abdel-Shafy, S. (2016) Morphological and molecular identification of the brown dog tick Rhipicephalus sanguineus and the camel tick Hyalomma dromedarii (Acari: Ixodidae) vectors of rickettsioses in Egypt. Vet. World, 9(10): 1087.

21. Aphale, D. and Kulkarni, A. (2018) Modifications and optimization of manual methods for polymerase chain reaction and $16 S$ rRNA gene sequencing quality community DNA extraction from goat rumen digesta. Vet. World, 11(7): 990-1000.

22. Wang, Z.L., Yang, X.Q., Wang, T.Z. and Yu, X. (2018) Assessing the effectiveness of mitochondrial COI and $16 \mathrm{~S}$ 
$r R N A$ genes for DNA barcoding of farmland spiders in China. Mitochondrial DNA A DNA Mapp. Seq. Anal., 29(5): 695-702.

23. Thompson, J.D., Higgins, D.G. and Gibson, T.J. (1994) CLUSTAL W: Improving the sensitivity of progressive multiple sequence alignment through sequence weighting, position-specific gap penalties and weight matrix choice. Nucleic Acids Res., 22(22): 4673-4680.

24. Kumar, S., Stecher, G. and Tamura, K. (2016) MEGA7: Molecular evolutionary genetics analysis version 7.0 for bigger datasets. Mol. Biol. Evol., 33(7): 1870-1874.

25. Kumar, S., Nei, M., Dudley, J. and Tamura, K. (2008) MEGA: A biologist-centric software for evolutionary analysis of DNA and protein sequences. Brief. Bioinform., 9(4): 299-306.

26. Saitou, N. and Nei, M. (1987) The neighbor-joining method: A new method for reconstructing phylogenetic trees. Mol. Biol. Evol., 4(4): 406-425.
27. Felsenstein, J. (1985) Confidence limits on phylogenies: An approach using the bootstrap. Evolution, 39(4): 783-791.

28. Tamura, K. and Nei, M. (1993) Estimation of the number of nucleotide substitutions in the control region of mitochondrial DNA in humans and chimpanzees. Mol. Biol. Evol., 10(3): 512-526.

29. Flannery, T. (1995) Mammals of the South-West Pacific and Moluccan Islands. Reed Books, Sydney.

30. Kusumaningrum, E.N. and Abinawanto, A. (2018) Implementation DNA Barcoding for Genetic Identification of Cuscus from Ambon Island. In: AIP Conference Proceedings. Vol. 2023. AIP Publishing LLC, Melville, NY. p020123.

31. Raterman, D., Meredith, R.W., Ruedas, L.A. and Springer, M.S. (2006) Phylogenetic relationships of the cuscuses and brushtail possums (Marsupialia: Phalangeridae) using the nuclear gene BRCA1. Aust. J. Zool., 54(5): 353-361. 